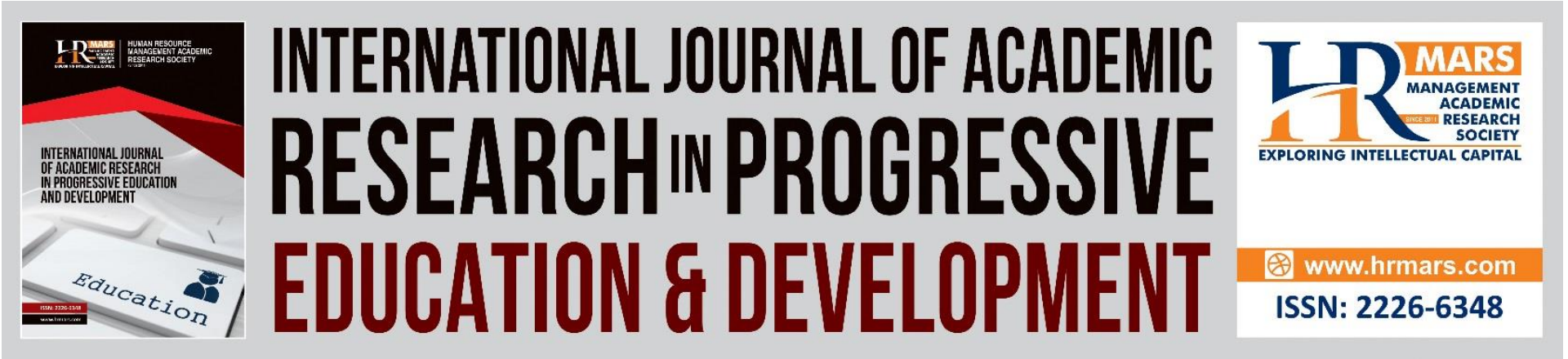

\title{
Green Technology: Awareness among Academic Library Employees
}

Norhayati Hussin and Amirah Hafit

To Link this Article: http://dx.doi.org/10.6007/IJARPED/v7-i3/4356

DOI: $10.6007 /$ IJARPED/v7-i3/4356

Received: 03 June 2018, Revised: 18 June 2018, Accepted: 03 July 2018

Published Online: 20 July 2018

In-Text Citation: (Hussin \& Hafit, 2018)

To Cite this Article: Hussin, N., \& Hafit, A. (2018). Green Technology: Awareness among Academic Library Employees. International Journal of Academic Research in Progressive Education and Development, 7(3), 161-177.

Copyright: (C) 2018 The Author(s)

Published by Human Resource Management Academic Research Society (www.hrmars.com)

This article is published under the Creative Commons Attribution (CC BY 4.0) license. Anyone may reproduce, distribute, translate and create derivative works of this article (for both commercial and non-commercial purposes), subject to full attribution to the original publication and authors. The full terms of this license may be seen

at: http://creativecommons.org/licences/by/4.0/legalcode

Vol. 7, No. 3, July 2018, Pg. 161 - 177

http://hrmars.com/index.php/pages/detail/IJARPED

JOURNAL HOMEPAGE

Full Terms \& Conditions of access and use can be found at

http://hrmars.com/index.php/pages/detail/publication-ethics 


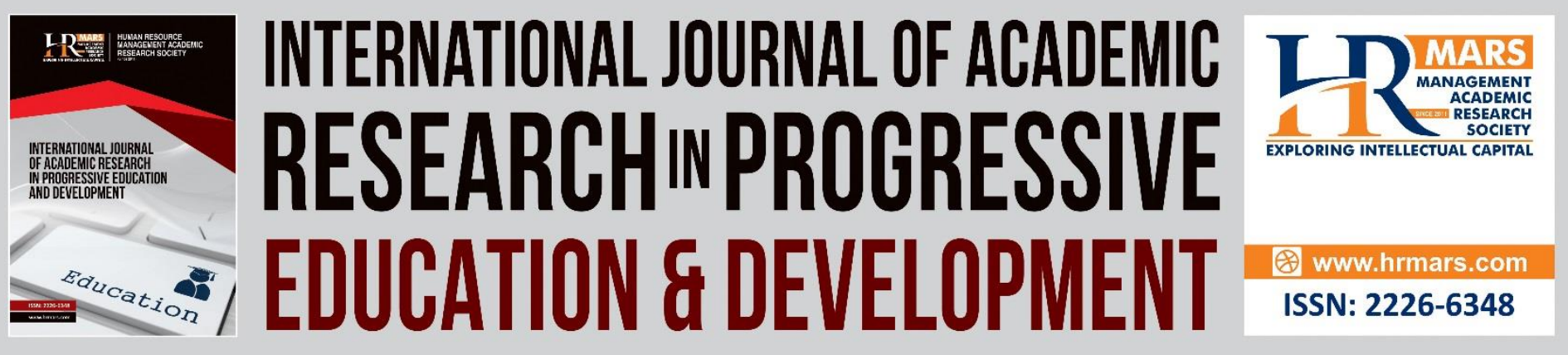

\title{
Green Technology: Awareness among Academic Library Employees
}

\author{
Norhayati Hussin and Amirah Hafit \\ Faculty of Information Management, Universiti Teknologi MARA (UiTM), UiTM Puncak \\ Perdana, UiTMSelangor, Malaysia \\ Email: yatihussin@salam.uitm.edu.my
}

\begin{abstract}
This study is being conducted to study the green technology awareness among IIUM Library staff. The place of this research is taken in IIUM Library Gombak with a total of 81 staff involved as a respondent. The systematic sampling method is used to select the respondent. The data is being collected either through email as well as by hand. The data is being analyzed by using SPSS software. The result shows that most of the respondents have a high level of understanding and basic knowledge of green technology but regarding practicing it, it is in moderate level. The study also shows that the most of the respondents that practice green technology in their daily routine are among assistant librarian female staff with a working experience below than five years. The main source of getting information in relating green technology is from the internet as it is a trend nowadays that all information is ready at the end of fingertips with the existence of the internet. Most of the respondents agreed that the green technology is costlier compared to the ordinary product. Despite that, the respondents are still willing to change towards environmentally friendly products. Also, the respondents feel that it is a responsible for each and everybody to protect the environment with the help of government as well in implementing green technology worldwide. In addition to the above, the practices on complying with practices need to be further boosted.
\end{abstract}

Keyword: Green Product, Library, Pollution, Recycling, Library Science

Introduction

It is stated that the world population keep on increasing from year to year. Based on statistic provided by Department of Economic and Social Affairs, United Nation (29 July 2015) claimed that the growth of population is currently 7.3 billion and will be over 8.5 billion in 2030. With the limited natural resources and high demand from the world community, the existing resources will not be enough to meet the satisfactory even the necessity. The growth of population will mean to show the increasing of natural resources and energy usage as well as the increment of pollutions on earth due to the hand of human being itself (Sadati, 2014). We can see that clearly, the unnatural change over climate as well as the rising temperature due to global warming as well as greenhouse effect are due to the open burning by agricultural activities, industrial fields and transportation sectors. 
All these phenomena effected in all countries including Malaysia. The last two years in 2015, Malaysia and Singapore have been cloaked with the haze that originally coming from the open burning by neighborhood country, Indonesia stated by Bernama, 12 May 2015. Several states even declared to be in dangerous zone due to the hazardous air and limited vision. This pollution had caused several problems where many daily activities got effected for example the delay of airplanes, the closing of schools as well as a serious health problem especially among children and old folks like skin irritation and asthma. We can see that with only one pollution which is through the air had caused many problems. How about other pollution like water pollution, land pollution and sound pollution that are occurred due to the hand of the human (Malaysian, 2015).

Due to all these phenomena occurrence, Malaysia government had taken a step forward to overcome this problem by establishing a Ministry of Energy, Green Technology and Water Malaysia (KeTTHA) in 2009. This establishment is formed to monitor and manage the existing resource in a strategic way in order to maintain the sustainability. In another word, the existence of KeTTHA is to make a Malaysia a green country through implementation of green technology. The definition of green technology can be defined in many ways as long as it upholds the maintaining the sustainability and maintain and conserve the ecosystem of the environment and at the same time reducing the existence of pollution to the extent of zero pollution (Yang \& Zhao, 2011).

Malaysia government has implemented several policies that take care of the sustainability of environment including National Environment Policy, National Climate Change Policy, and National Green Technology Policy (Teknologi, Dalam, Staf, Pertubuhan, \& Lpp, 2009). There are many programs as well as campaigns held by the governments in order to educate the Malaysian society with the implementation of green technology in daily life (Savita et al., 2016). Under a program of MyHIJAU as an initiative by the government, among the objectives of the program are to create an awareness and provide a knowledge for the society on the importance of the green technology and at the same time provide the guidelines in industrial sector to produce a product that is in line with the green product (Green \& Corporation, 2013).

Through the policies and guidelines provided by the Malaysia government, many industrial sectors which are one of the biggest contributions towards the pollution already started to follow and implementing the green technology in their products to reduce the pollutions and reducing waste products to the environment (Yang \& Zhao, 2011). Despite all the effort shows by the Malaysia government, the implementation of green technology is still not in satisfactory level as what has been mentioned by Sulaiman \& Abdul Rahman (2013). This is due to Malaysian society are still lacking in knowledge of green technology. They still not aware of the significance of the green technology in everyday life.

For the implementation of green technology to reach the satisfactory level, every aspect of the sector need to take part in the succession of the objectives highlighted by the government. The implementation of green technology does not include only in industrial sectors, but each in the society play an important role in the implementation to be efficient. Based on the research that has been done by UPM, the result shows that the level of green practice among the users is at moderate level. The outcome of the survey shows that the users are not willing to purchase green products (Sabri \& Yong, 2006). It can be concluded that even if the user has basic knowledge about green technology, without practice, nothing will change. Young generation is an important asset to the country as they will be the future 
policy maker. It is important to educate them about the environmental sustainability so that they will understand and start in practicing the green technology.

A library as a place for lifelong learning for the society can be a role model to implement the go green projects whereby these projects need the support from the government and the society as a whole. This paper aims to give an idea on what are factors that influence the awareness of green technology among the academic library staff by focusing on the following aspects which are through (i) understanding and (ii) practices. The question is, how far is the knowledge and practices about the green technology of the librarians who will be the role model to implement the go green?

\section{Literature Review \\ Understanding of Green Technology}

Understand can be described as to know on something or the meaning behind the word, know what someone is saying via language as a medium or through their body language, know how something or object to happen or operate, know about the feeling, behaviors, habits or situation of the surrounding. To have an understanding on something, knowledge is the main principal in receiving information about something. Knowledge as what has been defined by Leidner, 2001 is a convergence of information either by an individual or a group of society and develop it as a belief, personality as well as skills in order to achieve a certain level of self-satisfaction. The trend in knowledge considered as clear or implied knowledge (Popper, 2002). A knowledge can be in the form of oral and written. Knowledge can be classified into two types which are explicit knowledge and tacit knowledge. Explicit knowledge is 'knowing about'. Meanwhile, tacit knowledge is 'knowing how' is based on experience which influences to make a decision. By combining these two types of knowledge, there will be existence of sharing of information. Through the knowledge, it can create awareness or concern that will shape a positive attitude towards the environment. Environmental knowledge is playing an important role for the implementation of green technology to be achieved. From the understanding based on knowledge, a practical on how to implement green environment will follow as there has a strong basis to start something that is new (Palilonis, 2012).

As we all have bear in mind, the current resources supplied are finite resources where for a long term used, the resources may vanish from the earth in the future. Thus, the usage of the energy resources needs to be monitored. According to the U.S. Green Building Council, U.S. residential and commercial buildings account for $68 \%$ of electricity consumption and $39 \%$ of total energy use (Yudelson, 2007). Other practice that can be implemented to achieve the sustainability, the community need to reduce the carbon footprint that comes from the buildings. These carbon footprints are said to be the cause of greenhouse effect where the amount of carbon dioxide released into the air is greater than the average rate of normal gas (Time for Change, 2008). A simple practice that libraries can do for the wellbeing of the environment is by reducing the toxic chemical cleaners. Instead, using the natural cleaning products is much encourage able (Antonelli, 2008).

\section{Practices of Green Technology}

In "Go Green!" (2008), the article provides a brief glimpse of what libraries can do to conserve energy and help protect the environment. Much of what is mentioned in Neale's article is included in our survey for the Greensboro Public Library system. Neale states, "Once 
paper is used in the library, make efforts to recycle it. Put recycle bins in appropriate staff and public locations and mark them well." Neale also makes mention that screen savers do nothing for energy conservation. In fact, "Some screensavers may prevent the sleep mode from being activated." Also, of note, this article was originally published in 2006 to Nylink, a nonprofit organization of libraries.

In "Libraries Can Go Green" (2008), Barnes provides three preliminary areas where libraries should focus their greening priorities. The first is in adapting on building operations and maintenance practices to reduce, reuse, and recycle. The second is the inception of larger system-wide library projects such as occupancy sensors, green landscaping and running bookmobiles on biofuel. The third is for libraries to lead the way is by fostering environmental sustainability efforts within the entire community.

Dike (2007) performs a similar survey on academic libraries in her study "How green is the academic sector?" This study that addresses the results of a questionnaire survey investigating environmental practices in academic libraries of the United Kingdom. The study covered initiatives in the following areas: policy audits and targets; waste management; purchasing; energy management; buildings and grounds; staff and user education. In "Becoming Green and Sustainable" (2004), Le Ber and Gregory mention the following areas as relevant to the greening of academic libraries:

- weeded materials

- office paper/junk mail

- outdated computers

- obsolete media

- building utilities

With the economy recession facing the country, almost all of the organization was affected by the reduction of the budget by the government. This phenomenon also reflected all the libraries as well. Library needs to take a measure in allocating the budget regarding reducing electricity consumption. As the library has a long service hour with the need of airconditioning and lighting, the energy consumption seems crucial. (Wong, 2016). In his paper published titled "More than just a green building developing green strategies at the Chinese", Jones stated that by installing the motion sensor in the system, the energy used could be reduced to several percentages. (Jones, 2016). The time the lights stay on after a user has moved away was reduced to cut down the consumption of electricity. Shut down the computers, photocopiers and printers when library closes were practiced a long time ago. Every morning, the staff will no need to turn on the computers, only when the needed that the first staff that want to use it will switch on the machine. The practice seems fruitful since the annual energy consumption of the university library reduces down to eight percent. (Jones, \& Wong, 2016).

The other idea that has been a discussion from the previous research is by installing the HVAC system. HVAC stand for Heating, Ventilation and Air-Conditioning. As has been discussed by Linden (2012), this system has been known as a system that can reduce the energy consumption inside the building. HVAC has been implemented inside the building from the country with four seasons. The system will change the temperature based on the surrounding by using a temperature detector. During summer, the temperature will rise to a certain level set by the user. And it will happen during the winter season when the temperature detector detects the drop of temperature from the surrounding, the system will 
increase the temperature so that the environment is getting warm for the user comfort (Reilly, \& Herzog, 2012).

As we know that libraries need to have a preservation environment due to its contained materials conditions. Concerning the temperature and relative humidity, certain guidelines have been made. For example, the preservation of cultural materials must be in conditions at 708F and 50 percent RH, with minimal fluctuation (Sebera, 1994; Reilly, 1995). The existence of mechanical systems in library environments are designed to maintain the desired environmental conditions, usually cause a high cost in both monetary and energy consumption. By changing the system into HVAC, not many librarians are ready to implement with the operating schedule of the system. (Linden et al., 2012).

Based on the article "The human dimension of energy conservation and sustainability A case study of the University of Michigan's energy conservation program" it shows a significant change in how institutions taking care of their collections when it comes to environmental conditions for example the flat-line control of temperature and relative humidity conditions, gas-phase filtration, and upgrades to ultra-modern mechanical systems have all been implemented for collections preservation. Some of the standard guidelines focus on constant air volume, continuously running systems to maintain temperature and relative humidity conditions in collections areas where preservation is a priority (Marans, \& Edelstein, 2010).

Palilonis (2012) said that the empty cartridges could be returned to the selected company that use it for the business purposes. This practice will prevent from landfill and save the materials. Most of the companies who were doing business with the empty cartridges will pay with cash and the value per cartridges can be from 25 to 50 cents. For the empty laser printer cartridges, the value is much higher than the normal cartridges. Finally, postage-paid mailing envelops for ink cartridges, cell phones and other small electronic items will be mailed to a recycler. This service is a low effort method to recycle empty ink cartridges (A., Dempsey, \& Palilonis,. 2012).

\section{Awareness on the Importance of Green Technology}

Based on the analysis, it is shown that we are moving from the developing stage to the practicing stage, but the implementation of the green practices in libraries are still far away. We need to do on integrating green principles into our traditional business or service model and have not started on building and maintaining a green knowledgebase. The traditional library is changing as the digital library and green computing impact. But still, in terms of the financial cost, energy intensity and their carbon footprint have not yet been measured (Jones, \& Wong, 2016).

Wong (2016) said that for the friendly environmental library to be accepted by the community, the library itself needs to be the starter and role model to the community by practicing all the green activities. Such green activities will be resulting from a healthy environment and maintain the sustainability of the global development. The library building should implement green qualities of saving energy, recycling water, and generating energy with its solar panels, as well as the collection of rainwater for the recyclable water practice. Being a role model will give a great impact to the community from young generations on the old generation.

The benefits of the environmental friendly library, it increases the number of library visits. At the same level, the environmental friendly library should manage to attract many 
researchers as well as scholars at all over the world. This example can be found from the Beitou Branch Library in China. Based on Taipei Public Library (2007b) statistic, the book borrows from visitors increased positively from year to year. Furthermore, the environmental friendly library wills the typical thinking of public towards the library itself (Green, \& Movement, 2015).

\section{Methodology}

This research study is using quantitative research design because the purpose of the study is to find out the level of understanding, practices and their relationship of green technology among IIUM library staff. This study falls under descriptive research as it is using statistical analysis to calculate the mean, percentage and range. The research paradigm for this study will be positivism.

\section{Instrument}

In this research study, survey method is used to collect the data. The list of questionnaires is distributed to collect the information on how the staff think and act related to green technology. Pilot test is carried out before the actual survey is conducted. In order to ensure the validity of this research, the pilot survey is conducted among 30 participants of library staff. The instrument used in this research study is a questionnaire as to reduce the expenses, the time as well as the energy during conducting data collection.

The questionnaire mainly consists of two parts which are the first part is related to the demographic of the respondent such as the age, gender, position in the organization, period of working in the organization etc. The second part of the questionnaire comprises of three sub parts which covers the awareness of green technology in terms of the understanding on the green technology, the practices of green technology as well as the importance of green technology. The question used Likert Scale from 1-strongly agree to 5 -strongly disagree for an option answer to the respondents.

Data sources of this study are primary sources which are the questionnaires that is used in collecting the data information. Some of the questionnaire is handed personally depends on the position of the library staff, for example, the senior librarians is explained further in details personally to the respondents. The other method of distribution is through email. The link is given to the head of the respective division, and they then email the links to all staff under them.

The population of this study is 100 including both professional staff and support staff in all IIUM library that situated at Gombak campus. Under this research sampling, the sampling methods followed based on by Krejcie and Morgan (1970, in Chua Yan Piaw 2006) method. Based on the table provided by Krejcie, the number of the sample is $s=80$ for the mean is $n=100$.

\section{Data Analysis and Interpretation}

The data collected is inserted into the descriptive and inferential statistical methods software namely Statistical Package of Social Sciences (SPSS Version 24) for data processing and output interpretation purposes. The significant level for data analysis of $p \& \alpha=0.05$ is used in this study.

The questionnaire mainly consists of three parts which are the first part will relate to the demographic of the respondent such as gender, position in the organization, period of 
working experience in the organization and division. The second part of the questionnaire comprises of the understanding of the green technology, while the third part will be the practices of green technology among IIUM Library staff. The question used Likert Scale from 1-strongly agree to 5-strongly disagree for an option answer to the respondents as well multiple-choice questions.

\section{Result and Discussion}

\section{Respondent Background}

Table 1 list of the information on the respondent background where about 25 (30.9\%) respondents are from the male while $56(69.1 \%)$ are from the female. Regarding position in the organization, the statistic shows that there are 28 (34.6\%) librarians, 34 (42.0\%) assistant librarians and 19 (23.5) admin officers that have answered the questionnaire. For the working experience, the period is divided into four categories which are one to five years (1-5 years) which has the highest frequency of 26 (32.1\%) followed by the second highest frequency 23 $(28.4 \%)$ with the period between more than fifteen (15) years of experience. For six to ten years (6-10 years) of working experience, the frequency is the same with the respondents of working experience of eleven to fifteen years (11-15 years) with the frequency of 16 (19.8\%). All the respondents have come from various divisions with different number of frequency from the highest to the lowest number which are Cataloguing 18 (22.2\%), Acquisitions 17 (21\%), Administration 10 (12.3\%), Circulation and Lending 8 (9.9\%), Inter Library Loan (ILL) Fee Base 5 (6.2\%), Serials Services 5 (6.2\%), Information Services 4 (4.9\%), Research Support 4 (4.9\%), System Management 3 (3.7\%), Knowledge Management 3 (3.7\%), Collection Management $2(2.5 \%)$ and last but not least Government and Corporate Unit with frequency of $2(2.5 \%)$. Based on overall analysis of the demographic, it can be said that most of the respondents is among assistant librarians with a majority of female workers with working experience in the early phase regarding seniority.

Table 1. Information of Respondent Background ( $n=81$ )

\begin{tabular}{lcc}
\hline Variables & Frequency & $\begin{array}{c}\text { Percentage } \\
\text { (\%) }\end{array}$ \\
\hline Gender & & 30.9 \\
Male & 25 & 69.1 \\
Female & 56 & 34.6 \\
\hline Position & 28 & 42.0 \\
$\quad$ Librarian & 34 & \\
Asst. Librarian & & 23.5 \\
Others & 19 & 32.1 \\
Admin Officer & & 19.8 \\
\hline Experience & 26 & 19.8 \\
1-5 years & 16 & 28.4 \\
6-10 years & 16 & \\
11-15 years & 23 & 21.0 \\
More than 15 years & & 4.9 \\
\hline Division & 17 & 22.2 \\
Acquisitions & 4 & 9.9 \\
Information Services & 18 & 6.2 \\
Cataloguing & 8 & 5 \\
Circulation and Lending & 5 & \\
ILL-Fee Base & & \\
\hline
\end{tabular}


DEVELOPMENT

Vol. 7, No. 3, July 2018, E-ISSN: 2226-6348 @ 2018 HRMARS

\begin{tabular}{lcc}
\hline Administration & 10 & 12.3 \\
Serials Services & 5 & 6.2 \\
System Management & 3 & 3.7 \\
Others & & \\
Collection Management & 2 & 2.5 \\
Government and Corporate & 2 & 2.5 \\
Knowledge Management & 3 & 3.7 \\
Research Support & 4 & 4.9 \\
\hline
\end{tabular}

\section{Understanding on Green Technology}

Table 2 shows a result based on the respondent's level of understanding related to green technology with a scale given from $1=$ very weak to $5=$ very strong. About $45.7 \%$ of respondents have shown a strong understanding of the meaning of green technology. From the table, we can see that the highest frequency is coming from item six (6) where respondents have a strong understanding that green technology improves the quality of work life with a mean of 4.00 (54.3\%). With the second highest mean of 3.95 (44.4\%), respondents show a strong interest in green technology followed by a strong understanding of the purpose and benefit of using green technology with mean 3.83 (46.9\%). From item one, we can ensure that in overall the respondents understanding the meaning of green technology in general with high frequency of strong choice of mean 3.70 (45.7\%).

Table 2. Level of understanding on green technology

\begin{tabular}{lll}
\hline \multicolumn{1}{c}{ Statement } & \multicolumn{1}{c}{$\begin{array}{c}\text { Highest Freq. } \\
\text { (\%) }\end{array}$} & Mean \\
\hline $\begin{array}{ll}\text { I understand the meaning of green technology } \\
\text { I understand the purpose and benefit of using }\end{array}$ & $\begin{array}{l}\text { Strong (45.7) } \\
\text { green technology }\end{array}$ & 3.70 \\
I know that library practices green technology & $\begin{array}{l}\text { Moderate } \\
\text { (53.1) }\end{array}$ & 3.83 \\
I am interested in green technology & $\begin{array}{l}\text { Strong (44.4) } \\
\text { I use green technology in my daily routine }\end{array}$ & $\begin{array}{l}\text { Moderate } \\
\text { (51.9) }\end{array}$ \\
Green technology improves the quality of work life & Strong (54.3) & 3.95 \\
\hline
\end{tabular}

For the item number three and five in table 2 shows a moderate level in terms of practices of green technology at their workplace and the usage of green technology in their daily routine with a mean of $3.32(53.1 \%)$ and 3.32 (51.9\%) respectively. Majority of respondents agreed that their organization did not practices green technology directly by applying it to their standard of procedure (SOP). Despite that, the organization still give an encouragement for the workers to save energy by put an advertisement and pictures related to energy saving on every floor level near the lift where a crowd can see it with the goal it can give a motivation for the people surrounding to practice green technology for example by switching off the lamp when not in use or before leaving the place. This can be a proof based on the result tabulated in table 3 when the respondents give a highest selection on the definition of green technology which saves energy with the frequency of 70 (86.4\%). 
The second highest frequency shows the respondents have define green technology as a friendly to environment $68(84 \%)$ followed by green technology can reducing waste (recycling) with a frequency of 63 (77.8\%) while reduce the electric bill take up about 52 (64.2\%). Two of the respondents have selected with not family or not aware with what the green technology is about. It seems like the terms green technology is still unfamiliar to certain of respondents. The overall mean for understanding on green technology among respondents is 3.69 and thus, it can be said the level of understanding is higher where the respondents have a basic understanding and can define what green technology is about in general and this is in line with the study that has been conducted by Sabri and Yong (2006) and Sadati (2014) on surveying the environmental awareness.

Table 3. Definition of Green Technology

\begin{tabular}{lc}
\hline Statement & Frequency (\%) \\
\hline Save energy & $70(86.4)$ \\
Reduce the electric bill & $52(64.2)$ \\
Friendly to the environment & $68(84.0)$ \\
Reduce waste (Recycling) & $63(77.8)$ \\
Not aware / no idea at all / Not familiar & $2(2.5)$ \\
\hline
\end{tabular}

Table 4.Sources of getting to know about green technology

\begin{tabular}{lc}
\hline Variables & Frequency (\%) \\
\hline Newspaper & $49(60.5)$ \\
Magazine & $28(34.6)$ \\
Internet & $67(82.7)$ \\
Advertisement & $47(58.0)$ \\
Tele-broadcasting & $37(45.7)$ \\
\hline
\end{tabular}

Most of the respondents getting the information relating to green technology through the internet as it can be indicated based on Table 4 with the highest frequency of $67(82.7 \%)$ followed by a newspaper with frequency 49 (60.5\%). As expected, the current generations mostly rely on the internet as a source in getting information. Despite the development of technologies and information delivery systems keep on evolving, the techniques on seeking of information also differs in each of individuals to help in searching, teaching, and learning information. As the technology evolving, same goes to the information retrieval where internet is essential for every family household to have it. If not at home, they may reach it at their working place (Akussah, 2016). The lowest frequency shows that the respondents have selected magazine as their source of getting information related to green technology with the percentage of $34.6 \%$.

In Table 5, there three items that being asked towards the respondents with the option choice to answer either $1=y e s, 2=$ not sure or $3=$ no. The first item asks a question about whether the respondent ever had bought or using green technology product with a given an example like a paper bag, recycle paper and LED bulbs. 67 respondents out of 81 have chosen yes as the answer. This shows that ever since the government have started implementing 
green products by using a plastic bag at all market, people start to realize the importance and benefit of green products.

For item number two, the question asked whether respondent agrees with the statement does buy green technology products cost more than ordinary products. About $40.7 \%$ respondents have agreed that green technology products are quite costly compared to the ordinary one. Government should take initiatives to encourage people to use green technology products buy subsidizing these products so that people will have more reasons to change towards green the environment. This also has been stated in Table 6 where respondents have chosen government as the most responsible parties for protection of environment that giving a second highest of the frequency with $38.3 \%$.

Table 5. Perception on green technology

\begin{tabular}{|c|c|c|c|c|}
\hline Statement & Yes & $\begin{array}{l}\text { Not } \\
\text { Sure }\end{array}$ & No & Mean \\
\hline Did you buy any green technology product before? & $\begin{array}{c}67 \\
(82.7)\end{array}$ & $\begin{array}{c}12 \\
(14.8)\end{array}$ & $\begin{array}{c}2 \\
(2.5)\end{array}$ & 1.20 \\
\hline $\begin{array}{l}\text { Buying green technology products cost more than } \\
\text { ordinary products }\end{array}$ & $\begin{array}{c}33 \\
(40.7)\end{array}$ & $\begin{array}{c}25 \\
(30.9)\end{array}$ & $\begin{array}{c}23 \\
(28.4)\end{array}$ & 1.88 \\
\hline $\begin{array}{l}\text { Are you willing to start using green technology } \\
\text { products instead of ordinary products? }\end{array}$ & $\begin{array}{c}72 \\
(88.9)\end{array}$ & $\begin{array}{c}9 \\
(11.1)\end{array}$ & $\begin{array}{c}0 \\
(0.0)\end{array}$ & 1.11 \\
\hline Total Mean & & & & 1.40 \\
\hline
\end{tabular}

Table 6. Select the most responsible parties for protection of environment

\begin{tabular}{lc}
\hline \multicolumn{1}{c}{ Statement } & Frequency (\%) \\
\hline Government & $31(38.3)$ \\
Business organizations & $20(24.7)$ \\
National Council on the Environment & $12(14.8)$ \\
Nature Society & $11(13.6)$ \\
Everybody & $74(91.4)$ \\
\hline
\end{tabular}

For item number three in Table 5, the majority of respondents have shown their willingness to start using green technology products with the frequency of 72 (88.9\%). This result shows that even though they know the price of the green product is quite expensive compared to ordinary one, they still want to change it for the sake of the environment as well as for the future generation's benefits. It seems like people start to realize the importance of implementing green technology to everyday life (Savita et al., 2016). The importance of practicing green technology is applied for everybody as this can be seen in Table 6 where respondents have agreed that everybody is responsible for protecting the environment, not only government or certain parties do the works with the frequency choose for everybody highest 74 (91.4\%), followed by government 31 (38.3\%), business organizations 20 (24.7\%), National Council on the environment 12 (14.8\%) and Nature Society 11 (13.6\%). 
Business organization take the third place to be the most parties responsible for the environment protection. Through the policies and guidelines provided by the Malaysia government, many industrial sectors which are one of the biggest contributions towards the pollution already started to follow and implementing the green technology in their products to reduce the pollutions and reducing waste products to the environment (Yang \& Zhao, 2011). A clearer picture can be seen in the figure 6 . The perception of respondents towards green technology can be said as in moderate as the overall mean shows 1.40 a little bit below the average.

Practices of Green Technology

The last section of survey questionnaire was talking about the practices of green technology among IIUM library staff. The first of five items are related to practices or activities that have been done by the respondents with three optional answers given either 1=yes, 2=not sure/sometimes or $3=$ no. The first item asks respondent whether they know the nearest recycle bin or recycle center to their house. $59.3 \%$ of respondents selected yes as the answer while $7.4 \%$ respondents select no for their answers. 27 out of 81 respondents are not sure about the existence of the recycle bin. The second item asked whether the respondent ever had joined any campaign activities related with green technology, for example, recycling campaign and the result shows moderate where 35 of them have joined while another 35 respondents had never joined any of the activities and the rest of the respondents giving a not sure answer.

The respondents later on being asked whether they practice on separating the rubbish accordingly and it seems like about $59.1 \%$ of respondents sometimes choose as the answer. This result shows that this practices of sorting the rubbish according to its classes did not have been done in daily and did not make it as a habit. Only 28 respondents have select yes as their answer while another 11 respondents did not practice at all.

Item number three in Table 7 related to government policy where 'no plastic bag day' is being imposed to all supermarket since 2013 (Malaysiakini, 2016), the respondents are being asked whether they comply with the government policy or not and the result shows that $56.8 \%$ respondents do comply with the policy and $39.5 \%$ percent occasionally follow the policy by bringing their bag or using a biodegradable plastic bag provided. On the last item inquire respondents to decide whether they reproduce waste food as decomposed fertilizer, and only $24.7 \%$ respondents have practice it while $32.1 \%$ respondents did not practice it. This situation can be understood as it is quite hard for people to make the waste food as a decomposed fertilizer as not all of them have a suitable place or space to use it for fertilizer, or there are no recycle bin provided or unavailability of recycling center around residential areas and as we know that this practice requires an energy and effort, for example, classifying waste products accordingly requires effort and time consuming (Sabri 2016).

The overall mean for the practice of green technology among IIUM Library staff is 1.76, and thus it can be said it is moderate. The details of the analysis show that most of the respondents who have the highest frequency in practices of green technology are among female assistant librarian who had working experience 1-5 years. 
Table 7. Practices / activities of green technology

\begin{tabular}{lcccc}
\hline \multicolumn{1}{c}{ Statement } & Yes & $\begin{array}{c}\text { Not sure / } \\
\text { Sometimes }\end{array}$ & No & Mean \\
\hline Do you know the nearest recycle bin/ recycle center to your & 48 & 27 & $6(7.4)$ & 1.48 \\
house? & $(59.3)$ & $(33.3)$ & & \\
Have you ever joined any recycle campaign activities? & 35 & 11 & 35 & 2.00 \\
& $(43.2)$ & $(13.6)$ & $(43.2)$ & \\
& 28 & 42 & 11 & 1.79 \\
Do you separate the types of the rubbish accordingly? & $(34.6)$ & $(51.9)$ & $(13.6)$ & \\
& 46 & 32 & $3(3.7)$ & 1.47 \\
Do you comply with the government policy (No Plastic Day) & $46.8)$ & $(39.5)$ & & \\
by taking your own recycle bag rather than plastic beg & $(56.8)$ & & & \\
while shopping? & 20 & 35 & 26 & 2.07 \\
$\begin{array}{l}\text { Do you reproduce the waste food as other usage such as } \\
\text { decomposed fertilizer or home-made detergent? }\end{array} \quad(24.7)$ & $(43.2)$ & $(32.1)$ & \\
\hline$\quad$ Total Mean & & & & 1.76 \\
\hline
\end{tabular}

Table 8 shows a result on the frequency of action at home in daily routine by IIUM Library staff. This part of the questionnaire used a scale of 1=never, $2=$ rarely, $3=$ sometimes, $4=$ often and $5=a l w a y s$ for their optional answer. There are three items that have answer as always which are the frequency of keeping papers which are printed on one side in order to write on the other side, the frequency of using both sides of paper to avoid wastage and the frequency of turning off the lights in room which are not being used with the mean of 3.95, 4.10 and 4.32 respectively.

Table 8. Indicate the frequency of action at home/office

\begin{tabular}{|c|c|c|}
\hline Statement & $\begin{array}{l}\text { Highest } \\
\text { Freq. (\%) }\end{array}$ & Mean \\
\hline How often do you reuse items such as glass bottles? & Often (34.6) & 3.60 \\
\hline HOW OFTEN DO YOU CHOOSE PRODUCTS WITH GREEN LABELS? & $\begin{array}{l}\text { Sometimes } \\
(56.8)\end{array}$ & 3.21 \\
\hline HOW OFTEN DO YOU BUY PRODUCTS WITH A LOT OF PACKAGING? & $\begin{array}{l}\text { Sometimes } \\
\quad(58.0)\end{array}$ & 3.16 \\
\hline How often do you litter when nobody is watching? & $\begin{array}{l}\text { Never } \\
(45.7)\end{array}$ & 2.00 \\
\hline $\begin{array}{l}\text { How often do you keep papers which are printed on one side in order to } \\
\text { write on the other side? }\end{array}$ & $\begin{array}{l}\text { Always } \\
(35.8)\end{array}$ & 3.95 \\
\hline How often do you use both sides of the paper to avoid wastage? & $\begin{array}{l}\text { Always } \\
(38.3)\end{array}$ & 4.10 \\
\hline $\begin{array}{l}\text { HOW OFTEN DO YOU TURN OFF THE LIGHTS IN ROOMS WHICH ARE NOT } \\
\text { BEING USED? }\end{array}$ & $\begin{array}{l}\text { Always } \\
(54.3)\end{array}$ & 4.32 \\
\hline HOW OFTEN DO YOU USE THE AIR-CONDITIONER WHILE YOU SLEEP? & $\begin{array}{l}\text { Rarely } \\
(32.1)\end{array}$ & 2.64 \\
\hline $\begin{array}{l}\text { HOW OFTEN DO YOU GO TO AN EXHIBITION CONCERNING THE } \\
\text { ENVIRONMENT WHEN THERE IS A PUBLIC EXHIBITION? }\end{array}$ & $\begin{array}{l}\text { Sometimes } \\
(38.3)\end{array}$ & 2.64 \\
\hline Total Mean & & 3.29 \\
\hline
\end{tabular}

Three items are chosen as sometimes which are the frequency of choosing a product with green label, the frequency of buying a product with a lot of packaging and the frequency of going to an exhibition that related with environment concern with the mean of $3.21,3.16$ and 2.64 accordingly. A result from this study had found that $34.6 \%$ of respondents often reuse an item such as glass bottle in their daily routine. The highest percentage of item 
Vol. 7, No. 3, July 2018, E-ISSN: 2226-6348 @ 2018 HRMARS

seven shows that most of the respondents rarely use the air-conditioner while sleeping. This is due to several reasons which are it is costly regarding bills and not many use air-conditioners.

$45.7 \%$ of respondents had never littering while nobody is watching. This shows that it had become a habit for a respondent not to litter or throw rubbish not in the right place.

The overall mean for this part is 3.29 with four items that are above the overall mean where the respondent often reuse item such as glass bottles, keep papers which are printed of one side in order to write on the other side, use both sides of the paper to avoid wastage as well as turn off the lights in rooms which are not being used. One of the reasons for the item five and six to be high in frequency is due to the budget given by the university is being cut. Thus, the staff need to use all the papers wisely. Indirectly, this can help to reduce the waste of paper.

\section{Relationship Between Understanding and Practices of Green Technology}

Table 9. Relationship Between Level of Understanding and Level of Practices among IIUM Library Staff

\begin{tabular}{cc}
\hline Variable & $\begin{array}{c}\text { Level of practices } \\
\text { of green } \\
\text { technology }\end{array}$ \\
\hline $\begin{array}{c}\text { Level of } \\
\text { understanding on } \\
\text { green technology }\end{array}$ & $0.261^{*}$ \\
\hline Note: ${ }^{*} p \leq 0.05$
\end{tabular}

Table 9 shows a significant relationship between the level of understanding on green technology and the practices of green technology among IIUM Library staff $r(79)=0.26, p=$ 0.019. This shows that the higher the level of understanding, the higher the practices of green technology. A study conducted by Jamaluddin (2016) a person who has a higher concern with the environment will be more likely to buy a green product and practices more on recycling of product. The overall mean for the level of understanding on green technology is 3.69. The detail of analysis stated that there are four items that have men value greater that overall mean value which is they understand the meaning of green technology and purpose and benefit of using it, they are interested in green technology and agreed with the statement that green technology improves the quality of work life.

Most of the respondents have agreed that buying green technology products cost more than ordinary products based on Table 4.2.4 where the second item has a mean of 1.88 higher than overall mean of 1.40 . As the green technology is still in early stage of implementation in Malaysia, not many industries have implemented the green technology policy. With the high demand and less supply, the price of a green technology product is quite expensive compared to an ordinary product. Here, government plays an important role in the implementation of green technology to be more worldwide and successful by subsidizing green technology product as to encourage people to consume more green products instead of the ordinary one. In addition to the above analysis, it can be said that even though there is a significant positive relationship 
INTERNATIONAL JOURNAL OF ACADEMIC RESEARCH IN PROGRESSIVE EDUCATION AND DEVELOPMENT

Vol. 7, No. 3, July 2018, E-ISSN: 2226-6348 @ 2018 HRMARS

between both variables, the practices on complying with practices need to be further boosted. Thus, hypothesis $\mathrm{H} 1$ is tested and accepted for the significance of the relationship between understanding and practices of green technology.

\section{Conclusion and Suggestion}

Based on the overall analysis, the study found that the respondents from IIUM Library staff have a higher level of understanding on green technology with a moderate level of practices of green technology. The study also shows that most of the respondents that practices green technology in their daily routine are among assistant librarian female staff with a working experience below than five years. The main source of getting information in relating green technology is from the internet as it is a trend nowadays that all information is ready at the end of fingertips with the existence of the internet. Most of the respondents agreed that the green technology is costlier compared to an ordinary product. Despite that, the respondents are still willing to change towards environmentally friendly products. Also, the respondents feel that it is a responsible for each and everybody to protect the environment with the help of government as well in implementing green technology worldwide.

As we can see from this study, even though most of the respondents understand and have basic knowledge of green technology, regarding practice it is still not in satisfaction level. Thus, the government need to find initiatives to create awareness worldwide by making a collaboration with other non-government organizations such as Nature society to have a campaign or create activities that promoting the green technology. It is recommended that future curricula at primary and secondary levels need to apply education to the environment in education. Education at this early stage is crucial to forming individual behavior when mature. In this aspect, teachers play an important role in guiding and promoting the younger generation to practice a sustainable or eco-friendly way of life.

The environmental friendly library still did not be a concern for the developing countries. It is contras with the developed countries where the green activities have been their practices in almost in every aspect of their daily lives as they have realized the importance and benefits for themselves as well as the future generations. With the rises of pollution and increases of the greenhouse effect at the global level, actions must be taken to prevent the current problems become worst. With the first steps taken by the library to be a role model to the community, these efforts will be fruitful at least for the young generations to start realized and appreciated the importance of the resources given as well as not to repeat the mistakes made by the previous generations.

\section{References}

Ahenkorah-Marfo, M., \& Akussah, H. (2016). Being where the users are: readiness of academic librarians to satisfy information needs of users through social media. Library. https://doi.org/10.1108/LR-02-2016-0020

Authors, F. (2009). The efficiency of Estonian central public libraries. https://doi.org/10.1108/14678040910949684

Bakar, K. A., Fazli, M., Sam, M., Tahir, N. H., Rajiani, I., \& Muslan, N. (2011). Green Technology Readiness In Malaysia : Sustainability For Business Development, 1120-1129.

Ben, N. (2015). Determinants Of Green Information Technology Awareness, (December). 
INTERNATIONAL JOURNAL OF ACADEMIC RESEARCH IN PROGRESSIVE EDUCATION AND DEVELOPMENT

Vol. 7, No. 3, July 2018, E-ISSN: 2226-6348 @ 2018 HRMARS

Dempsey, M. E., Palilonis, A., Dempsey, M. E., \& Palilonis, A. (2012). a greener library with print management. https://doi.org/10.1108/07378831211266555

Fourie, I., \& Fourie, I. (2012). A call for libraries to go green An information behavior perspective to draw interest from twenty-first century librarians.

https://doi.org/10.1108/07378831211266573

Green, G., \& Movement, G. L. (2015). GREEN LIBRARIES : MEANING , STANDARDS AND PRACTICES By Ramyia Krishnan Pangail, 4(3), 1-9.

Hussong-christian, U., \& Hussong-christian, U. (2016). If you build it, will they sort it ? Compost collection in the academic library learning commons. https://doi.org/10.1108/LM-04-20160026

Jamaluddin, F., \& Ibrahim, A. (2016). Examining the Relationship Between Environmental Awareness and Government Towards Green Technology Implementation Among, 1(5), 196-204.

Jones, L., \& Wong, W. (2016). More than just a green building Developing green strategies at the Chinese. https://doi.org/10.1108/LM-05-2016-0041

Kristanto, G. A., Priadi, C., Orientilize, M., Udhiarto, A., \& Bahsan, E. (2014). Towards Green and Sustainable Society: A Case of Engineering Faculty, Universitas Indonesia, (March), 19-21.

Kruse, T., \& Kruse, T. (2012). Greener library printing and copying. https://doi.org/10.1108/08880451111186053

Linden, J., Reilly, J., Herzog, P., Linden, J., Reilly, J., \& Herzog, P. (2012). Research on energy savings opportunities in university libraries. https://doi.org/10.1108/07378831211266537

Malik, A., \& Rahman, A. (2010). Greening The Architectural Curriculum In All The Malaysian Institutes Of Higher Learning- It Is Not An Option, 4(November), 44-54.

Marans, R. W., \& Edelstein, J. Y. (2010). The human dimension of energy conservation and sustainability A case study of the University of Michigan ' s energy conservation program. https://doi.org/10.1108/14676371011010011

Mazanova, O. (n.d.). ON SOME PROBLEMS OF THE CREATION AND DEVELOPMENT OF GREEN TECHNOLOGIES IN.

Ong, J. (2012). Factors affecting adoption of green technology by firms in Kenya, 8188.

Rezai, G., Kit Teng, P., Mohamed, Z., \& Nasir Shamsudin Senior Lecturer, M. (2013). Going Green: Survey of Perceptions and Intentions Among Malaysian Consumers. International Business and Management, 6(61), 104-112. https://doi.org/10.3968/j.ibm.1923842820130601.1125

Rohani, S. (2013). Kesedaran Teknologi Hijau Dalam Kalangan Warga Universiti Tun Hussein Onn Malaysia, 1-112. https://doi.org/10.1017/CBO9781107415324.004

Rozelanyunus, A., Mohamad, M. A., \& Paper, F. (2015). Jurnal Teknologi MALAYSIAN AWARENESS \& PRACTICES OF GREEN TECHNOLOGY : A CASE OF, 1, 1-5.

Sabir, U., Ariwa, E., \& Taylor, A. (2013). Green Technology and Energy Management Systems in Developing Countries : A Case Study of Pakistan Textile Industry, (September 2004), 20042006. https://doi.org/10.4236/epe.2011.33045.

Sabri, M. F., \& Yong, T. Y. (2006). Tahap Keprihatinan Alam Sekitar dan Amalan Kepenggunaan Hijau Pengguna di Petaling Jaya, Selangor. Pertanika Journal of Social Science \& Humanities, 14(2), 95-109. 


\section{INTERNATIONAL JOURNAL OF ACADEMIC RESEARCH IN PROGRESSIVE EDUCATION AND}

\section{DEVELOPMENT}

Vol. 7, No. 3, July 2018, E-ISSN: 2226-6348 @ 2018 HRMARS

Sadati, S. (2014). Surveying Environmental Awareness- A Green Education Agenda : The Case of Eastern Mediterranean University.

Savita, K. S., Subarna, S., Savita, K. S., Thivaanraj, Y. M., Subarna, S., Manoranjitham, M., ... Manoranjitham, M. (2016). User Perception on Environmental Friendly Practices among Primary Schoolchildren in Perak User Perception on Environmental Friendly Practices Among Primary Schoolchildren in Perak, 667-672.

Soares, N. (2015). Energy efficiency of higher education buildings : a case study. https://doi.org/10.1108/IJSHE-11-2013-0147

Teknologi, K., Dalam, H., Staf, K., Pertubuhan, L., \& Lpp, P. (2009). Green Technology Awareness Among Lembaga Pertubuhan Peladang ( LPP ) Staff, (April).

Tseng, S. (2012). Green library design and evaluation : the Taipei Public Library, Taiwan. https://doi.org/10.1108/03074800810888159

Yang, C., \& Zhao, H. (2011). Barriers to Green Technology Innovation in Large and Medium ü sized Enterprises. https://doi.org/10.1109/ICM.2011.350 